\title{
THE FINANCES OF THE CIVIL SOCIETY IN UKRAINE: KEY TRENDS, MODELS AND OBSTACLES IN ACHIEVING SUSTAINABILITY
}

The financial viability is one of the most important element in achieving sustainability for a civil society, especially in post-Socialist states of Eastern and Central Europe. Despite positive assessments of the role and potential of civil society in Ukraine from scholars and analysts and comparatively high score of civil society organizations' sustainability index taking in comparative perspective for a whole region, its financial capabilities remains its weakest part during decades of Ukrainian independence. Having comparatively friendly legal and political environment and achieving some impressive results in advocacy, building coalitions and networks and enhancing its organization capabilities Ukrainian CSOs still remain dependant from international donors. Some shifts in financial resilience of civil society demands not only efforts from its side, but finding a consensus with a state on the model to achieve.

Three typical models of interrelations by civil society and government, emerged in contemporary Europe are provided, they could be distinguished based on the social and political role of CSOs and their functions in public services provision. These models based on the scales of institutionalization and level of independence of civil society relatively to the authorities and include Social-democratic (Scandinavian), Liberal (Anglo-Saxon) and Corporativism (Continental) types. Ukrainian civil society, regardless achievements in organizational capacities and sectoral infrastructure, still remains in the "emerging» transitional spot due to the extremely small amount of public funds it attracts and based on uncertainty of its role on national and local level.

Perspective destinations for civic-state dialogue are emphasized, among which there are finding the consensus of desired model and adopting new National Strategy of Stimulation Civil Society in Ukraine for next five years, changes in legal framework for local self-government, social entrepreneurship, taxation of charity and means earned by CSO themselves and establishing new practices and institutions for public financing of CSOS on national and regional levels.

Key words: civil society, civil society organizations, non-governmental organizations, financial viability, public funds, international donors, social entrepreneurship

\author{
Біденко Юлія Михайлівна \\ доц. канд. політ.н, \\ Харківський національний \\ університет імені В.Н. Каразіна, \\ пл. Свободи 4, Харків, 61022, \\ j.bidenko@karazin.ua, \\ http://orcid.org/0000-0002-0791-2569
}

\section{ФІНАНСИ ГРОМАДЯНСЬКОГО СУСПІЛЬСТВА В УКРАЇНІ: КЛЮЧОВІ ТЕНДЕНЦЇ̈, МОДЕЛІ ТА ПЕРЕШКОДИ В ДОСЯГНЕННІ СТАЛОСТІ}

Фінансова життєздатність є одним з найважливіших елементів досягнення сталості громадянського суспільства, особливо в постсоціалістичних державах Східної та Центральної Свропи. Незважаючи на позитивні оцінки ролі та потенціалу громадянського

(C) Bidenko Y., 2019. 
суспільства в Україні науковців та аналітиків, а також достатньо високий показник стійкості організацій громадянського суспільства в порівняльній перспективі регіону в иілому, його фінансові можливості залишаються найслабшою складовою протягом десятиліть української незалежності. Маючи відносно сприятливе правове та політичне середовище, досягнувщи значних результатів в адвокації, розбудові коаліиій та мереж та посиленні організачійних можливостей, украӥнські ОГС як і раніме залитаються залежними від іноземних донорів. Позитивні зрушення у фінансовій стійкості громадянського суспільства вимагають не лише зусиль з його боку, а й пошуку консенсусу з державою щодо оптимальної моделі для досягнення.

Запропоновано три типові моделі взаємозв'язків громадянського суспільства та влади, що склалися в сучасній Свропі, які виділено виходячи із сочіальної та політичної ролі ОГС та їх функиій у наданні державних послуг. Ці моделі трунтуються на масштабах інституціоналізації та рівні незалежності громадянського суспільства від органів управління та включають соиіал-демократичний (скандинавський), ліберальний (англосаксонський) та корпоративістський (континентальний) типи. Украӥнське громадянське суспільство все ще залишається в «перехідному» транзитивному стані через надзвичайно малий обсяг державних коштів, який воно залучає, та виходячи з невизначеності ролі на начіональному та місиевому рівні.

Підкреслюються перспективні напрямки державно-громадянського діалогу, серед яких пошук консенсусу щодо бажаної моделі та прийняття нової Національної стратегї стимулювання громадянського суспільства в Україні на наступні п’ять років, зміни в законодавстві про місцеве самоврядування, сочіальне підприємнищтво, оподаткування благодійної діяльності та коштів, зароблених НУО самостійно, а також створення нових практик та інститутів державного фінансування ОГС на нащіональному та регіональному рівнях.

Ключові слова: громадянське суспільство, організаиії громадянського суспільства, неурядові організаиіі, фінансова життєздатність, міжнародні донори, публічні фонди, сочіальне підприємництво

\section{Биденко Юлия Михайловна}

доц., канд.полит.н.,

Харьковский национальный университет имени В.Н. Каразина пл. Свободы, 4, Харьков, 61022 j.bidenko@karazin.ua http://orcid.org/0000-0002-0791-2569

\section{ФИНАНСЫ ГРАЖДАНСКОГО ОБЩЕСТВА В УКРАИНЕ: КЛЮЧЕВЫЕ ТЕНДЕНЦИИ, МОДЕЛИ И ПРЕПЯТСТВИЯ В ДОСТИЖЕНИИ УСТОЙЧИВОСТИ}

Финансовая жизнеспособность является одним из важнейших элементов достижения устойчивости гражданского общества, особенно в пост-социалистических государствах Восточной и Центральной Европь. Несмотря на положительные оценки роли и потенциала гражданского общества в Украине ученых и аналитиков, а также достаточно высокий показатель индекса устойчивости организаций гражданского общества в сравнительной перспективе региона в целом, его финансовые возможности остаются самой слабой частью на протяжении десятилетий украинской независимости. Имея сравнительно благоприятные правовые и политические условия и достигнув определенных результатов в адвокации, создании коалиций и сетей, расширяя своих организационных возможностей, украинские ОГО по-прежнему остаются зависимыми от международных доноров. Позитивные сдвиги в финансовой устойчивости гражданского общества требуют не только усилий с его стороны, но и достижения консенсуса с государством в отношении оптимальной модели для достижения.

Представлены три типичные модели взаимоотномений гражданского общества и правительства, появившиеся в современной Европе, различающиеся исходя из сочиальной и политической роли ОГО, а также и их функций в предоставлении государственных услуг. Эти модели основань на масштабах институционализащии и уровне независимости гражданского общества относительно органов власти и включают в себя социал- 
демократический (скандинавский), либеральный (англо-саксонский) и корпоративный (континентальный) типы. Украинское гражданское общество, несмотря на достижения в организационном потенциале и отраслевой инфраструктуре, по-прежнему остается в «переходном» транзитивном секторе из-за крайне малого объема государственных средств, которые оно привлекает, и по причине неопределенности его роли на начиональном $и$ местном уровнях.

Подчеркиваются перспективные направления для общественно-государственного диалога, среди которых поиск консенсуса относительно желаемой модели и принятие новой Национальной стратегии стимулирования гражданского общества в Украине на следующие пять лет, изменения законодательства о местном самоуправлении, соииальном предпринимательстве, налогообложения благотворительности и средств, зарабатываемыми НПО самостоятельно, а также создание новых практик и институтов для государственного финансирования ОГО на национальном и региональном уровнях

Ключевые слова: гражданское общество, организаџии гражданского общества, неправительственные организачии, финансовая жизнеспособность, международные доноры, публичные фонды, социальное предпринимательство

Civil society is widely understood as the space outside the family, market and state (Cooper 2018: 2). What constitutes civil society has developed and grown since the term first became popular in the 1980 s and it now signifies a wide range of organised and organic groups including nongovernmental organisations (NGOs), trade unions, social movements, grassroots organisations, online networks and communities, and faith groups (VanDyck 2017; WEF 2013). Anheir define civil society as the sum of institutions and active citizens located between the family, the state and the market- and as a space in which people associate voluntarily to advance common interests (Anheier 2004).

According to various evaluations by scholars (See: Hale 2014; Lutsevych 2017, Way, 2014 and others) and indexes (Nations in Transit by Freedom House, Civil Society Organizations Sustainability Index by USAID) Ukrainian civil society maintained outstanding results comparatively to others post-Soviet countries and considered to be one of the main drivers in democratic changes. For example, Lutsevych wrote: «across the post-Soviet space, Ukraine impresses observers as the most emancipated polity, its citizens ready to rise up for their rights against authority. In the past 15 years alone, Ukrainians have responded twice to injustice on the part of the ruling elite with powerful protest. In 2004 they revolted against a stolen election, and in 2014 against stolen aspirations for a closer relationship with Europe. In this context, the Euromaidan paved the way for a different political establishment that pledged to reform Ukraine and restore justice» (Lutsevych 2009: 59). Some of researches have got more sceptical towards Ukrainian civil society potential to influence over politics and led the reforms, especially in front of 2019 elections upcoming (Burlyuk and Shapovalova 2018; Smagliy 2018), but from the other side, the fact that civil society remains one of the strong stakeholder of democratization and EU integration of Ukraine is hard to deny, especially taking into account that under the populist rule of one political party it could appear to be one from a very few actors, still interested in developing democracy there.

Jezard (2018) claims that NGOs across 40 countries represent $\$ 2.2$ trillion in operating expenditures, what is larger than the gross domestic product of all but six countries. Civic sector also employs around 54 million full-time equivalent workers and has a global volunteer workforce of over 350 million. Due to contemporary shift in typical roles of civil society as non-profit and non-governmental hobby or watchdog organizations, new definitions and approaches from academia and practitioners are under appearance regarding its new actors and functions in social entrepreneurships, creative industries, education, social and youth policies.

That's why to overview the main developments of such important component of civil society as its financial sustainability is one of the main purposes of this paper, and among its tasks are: to trace the dynamics and main components of civil society sustainability index for Ukraine in comparative perspective, to analyse main models of the financial viability of civil society appeared in Europe, to research key trends in state and foreign financing of civic sector in Ukraine and to overlook public attitudes towards public and private sources for civil organizations' activities and initiatives.

Ukraine's Civil Society Sustainability Index (further CSOSI) 2018 score of 3.2 still remains the highest in the post-Soviet region 
(USAID CSOSI, 2019). CSOSI in general based on 7 criteria (legal environment, organizational capacity, financial viability, advocacy, service provision, sectoral infrastructure and public image) and the lower is overall score the more sustainable civil society is in general in the particulailar country. From the Figure 1 one can see that as on 2018 comparatively to the others post-Soviet states (excluding Central Asia and Baltic regions) Ukraine has the highest score of the CSO Index taken in general, and it's close to the ranking of Black See' region EU-Members and some of Visegrad countries, like Hungary.

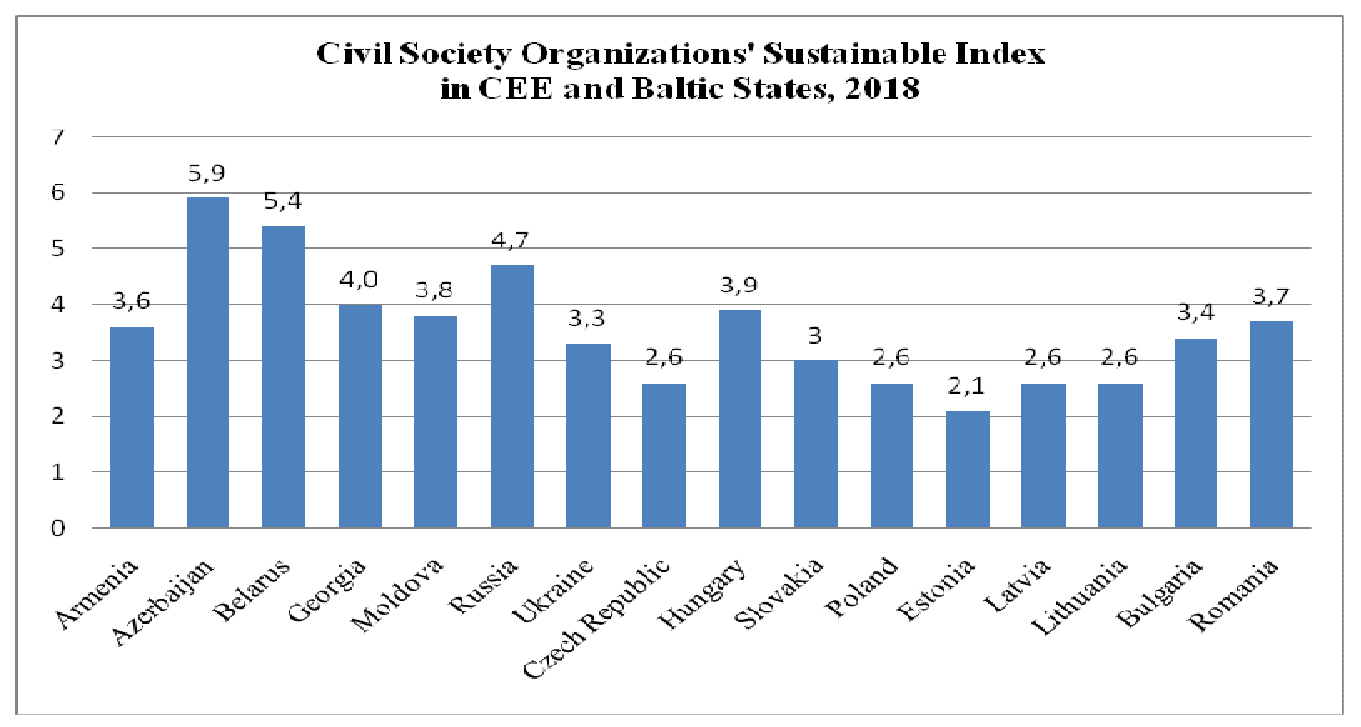

Figure 1. The 2018 ${ }^{\text {th }}$ Civil Society Organizations Index in European Region for Selected Countries of Post-Socialistic Region. Composed by author based on the $2018^{\text {th }}$ CSO Sustainability Index for Central and Eastern Europe and Eurasia (USAID CSOSI, 2019).

But this sustainability looks pretty fragile looking precisely from the point of view of its financial basis, for instance in Ukraine financial viability is the weakest feature of civil society comparatively to the both - EU-members states as to 2018 and to others indicators for the country taken in dynamics (see Table 1).

Table 1.

Dynamics of Civil Society Organizations Sustainability Index' Indicators for Ukraine

\begin{tabular}{|l|c|c|c|c|c|c|c|c|}
\hline Year & $\begin{array}{l}\text { Legal } \\
\text { Environ } \\
\text { ment }\end{array}$ & $\begin{array}{l}\text { Organiz } \\
\text { ational } \\
\text { Capacity }\end{array}$ & $\begin{array}{l}\text { Finan } \\
\text { cial } \\
\text { Viability }\end{array}$ & Advocacy & $\begin{array}{l}\text { Service } \\
\text { Provision }\end{array}$ & $\begin{array}{l}\text { Sectoral } \\
\text { Infrastru } \\
\text { cture }\end{array}$ & $\begin{array}{l}\text { Public } \\
\text { Image }\end{array}$ & $\begin{array}{l}\text { CSOI } \\
\text { Overall }\end{array}$ \\
\hline 2018 & 3,6 & 3,2 & $\mathbf{4 , 1}$ & 2,2 & 3,2 & 3,2 & 3,3 & 3,3 \\
\hline 2017 & 3,5 & 3,2 & $\mathbf{4 , 2}$ & 2,1 & 3,2 & 3,2 & 3,3 & 3,2 \\
\hline 2016 & 3,4 & 3,3 & $\mathbf{4 , 2}$ & 2,2 & 3,2 & 3,3 & 3,3 & 3,3 \\
\hline 2015 & 3,4 & 3,3 & $\mathbf{4 , 2}$ & 2,3 & 3,2 & 3,4 & 3,3 & 3,3 \\
\hline 2014 & 3,4 & 3,3 & $\mathbf{4 , 2}$ & 2,3 & 3,2 & 3,4 & 3,4 & 3,3 \\
\hline 2013 & 3,4 & 3,4 & $\mathbf{4 , 2}$ & 2,3 & 3,3 & 3,4 & 3,5 & 3,4 \\
\hline 2012 & 3,5 & 3,4 & $\mathbf{4 , 3}$ & 2,5 & 3,3 & 3,4 & 3,6 & 3,4 \\
\hline 2011 & 3,5 & 3,5 & $\mathbf{4 , 3}$ & 2,6 & 3,3 & 3,4 & 3,6 & 3,5 \\
\hline 2010 & 3,6 & 3,5 & $\mathbf{4 , 2}$ & 2,7 & 3,3 & 3,5 & 3,7 & 3,5 \\
\hline 2009 & 3,6 & 3,6 & $\mathbf{4 , 2}$ & 2,8 & 3,3 & 3,5 & 3,8 & 3,5 \\
\hline 2008 & 3,6 & 3,7 & $\mathbf{4 , 1}$ & 2,9 & 3,3 & 3,5 & 3,9 & 3,6 \\
\hline 2007 & 3,6 & 3,7 & $\mathbf{4 , 2}$ & 2,9 & 3,3 & 3,5 & 3,9 & 3,6 \\
\hline 2006 & & 3,7 & $\mathbf{4 , 3}$ & 3 & & & 4 & 3,8 \\
\hline
\end{tabular}


Вісник ХНУ імені В. Н. Каразіна, серія «Питання політології», вип. 36, 2019

\begin{tabular}{|l|c|c|c|c|c|c|c|c|}
\hline 2005 & 3,7 & 3,7 & $\mathbf{4 , 4}$ & 3,1 & 3,3 & 3,6 & 4 & 3,7 \\
\hline 2004 & 3,6 & 3,9 & $\mathbf{4 , 6}$ & 3,1 & 3,3 & 3,8 & 4,1 & 3,8 \\
\hline 2003 & 4 & 3,9 & $\mathbf{4 , 8}$ & 3,4 & 3,3 & 3,5 & 4,4 & 3,9 \\
\hline 2002 & 4,5 & 3,5 & $\mathbf{5}$ & 3,5 & 3 & 3,5 & 5 & 4 \\
\hline 2001 & 5 & 4 & $\mathbf{5}$ & 4 & 3 & 4 & 5 & 4,3 \\
\hline 2000 & 5 & 4 & $\mathbf{5}$ & 4 & 4 & 4 & 5 & 4,4 \\
\hline 1999 & 5 & 3,5 & $\mathbf{5}$ & 5 & 2,5 & 3,5 & 4 & 4,1 \\
\hline 1998 & 4,6 & 3,7 & $\mathbf{4 , 6}$ & 4,4 & & & 3,9 & 4,2 \\
\hline 1997 & 4 & 4 & $\mathbf{4}$ & 4 & & & 4 & 4 \\
\hline
\end{tabular}

Composed by author based on USAID CSOSI 2013-2018, Europe and Eurasia CSOSI Data 1997-2012

Regardless the fact that financial viability of Ukrainian civil society organizations slightly improved during last years it's still far from maintaining sustainability. The simple explanations could be found in the economy reasons such as crisis, export reorientation, huge part of shadowed business and slow economy growth, or in social burden, affected by the conflict in and around Ukraine, and at last, in Soviet legacy in general, including poor social capital and deformed civic culture, suffered from the lack of trust and destroyed traditions of charity.

But there are some more recent obstacles appeared during the last decades, among which are the dependence of foreign donors' costs, gaps between NGOs in the capital and regions in financial capacities, the lack of taxations relief and stimulations for business and individuals and, what is more important, the absence of clear common vision from the state and civil society of their shared goals and interrelations in long-term perspective.

Despite the adoption of National Strategy for Supporting Civil Society Development for 2016-2020 on February 2016, it was and still is unclear what type of civil society it stimulates and what kind of relations between public authorities and the third sector should be established. From the one point of view, Strategy proclaimed the importance of public finances for civil sector sustainability, as well as the intentions to simplify the regulations for charity activities by private donors and individuals, from the other side, no clear goals, indicators and timelines wasn't established there. As to me, the main problem of National Strategy which made it declarative but inefficient, was that it didn't refer to any clear model of civil society to achieve.

Since $2010^{\text {th }}$ a numerous recommendations from the OSCE, Council of Europe and European Union were provided, some of them included the optional models grounded on public funds usage adopted by European states already. Generalized types of civil society and its interrelations with governmental and business sectors could be allocated depending on the degree of independence and institutialization. Sator (2010) using these criteria and focusing on the share of direct budget support provided to the CSOs, primarily in the form of government grants but also subsidies and in-kind contribution, at both the central and the local level, outlines four types of civil society in Europe, what can be visualized by the Figure 2 .

\begin{tabular}{|c|c|c|}
\hline \multirow{4}{*}{} & \multicolumn{2}{|c|}{ More Independent } \\
\cline { 2 - 3 } & $\begin{array}{c}\text { Socio-Democratic (Scandinavian) } \\
\text { Autonomy }\end{array}$ & $\begin{array}{c}\text { Liberal } \\
\text { (Ango-Saxon) }\end{array}$ \\
Partnership \\
(Public Funds are 20-30\%)
\end{tabular}

Figure 2. Composed by author, based on Sator (2010) p. 15-17. 
The scale of independence is related to the autonomous self-governance of CSOs vis-à-vis the government or other actors (e.g. church, political parties); reflected in the CSOs capability to mobilize themselves and their constituencies, obtain financial support needed to carry out their mission, ability to deliver services that are not or partially subsidized, develop competitive expertise etc. In essence, it refers to the extent to which CSOs are able to set priorities and operate based on needs and their mission rather than based on priorities set by the government or other power structures.

Institutionalization refers to the capacity of the non-profit sector to undertake projects and services for the government, i.e. the potential of the sector to be a reliable and accountable partner to the government in providing public goods and services. This includes for example, the number of registered organizations, their average budgets, the proportion of CSOs who are of public benefit, their physical infrastructure as well as their human and financial resources etc (Sator 2010: 14).

In the Liberal (presented in United Kingdom, Netherlands and Canada) model CSOs are also highly involved in social services' provision, however, they are less dependent on the state. Even though they receive financing through contracts, they have strong roots in the communities; and their own assets, philanthropic and self-generated income make them able to keep also a strong advocacy role. In the liberal model the principle of the best value service delivery 13 makes the CSO sector very professional and competitive. Various models of management, accountability and transparency standards are applied; sophisticated management schemes are widespread to increase trust and confidence of all stakeholders. While there is a significant level of public financing applied in these countries (35-55\%), the level of other resources is high which makes the sectors more relevant in terms of partnership for the government.

Social-Democratic (Scandinavian) model build on the role of the state as the main service provider meanwhile NGOs are not typically involved in provision of social services but rather fulfil «expressive» functions (i.e. cultural, sports, hobby organizations that primarily serve their members' and their communities' interests). Even though almost everything in welfare provision is financed and delivered by the state, in contrast to the «statist» model of the former Soviet bloc, there is a high level of social capital and engagement in civil society (volunteering reaches the highest levels in
Europe in these countries). The relationship between the two sectors can be characterized by the «live and let live» philosophy and consequently a low level of public funding of CSOs $(25-35 \%)$. At the same time citizens and CSOs are extensively and directly involved in policy making both at local and central levels and civil society tends to be more of a watchdog and advocacy character, its funding is strongly based on private giving and membership support. In regards to institutionalization this sector is less established, as CSOs don't need massive operations that are needed for services, while due to inclusive democratic practices there is less need for such capacity even in case of advocacy operations.

Corporatist (Continental) model supposed that CSOs are actively involved in the provision of social services and may be the main providers - as in the case of Germany where the principle of subsidiarity entails the primacy of community-based services. At the same time the state undertakes financing of the services in whole, typically through third party payments or subsidies to major providers and their interest groups. State funding thus represents well over half (usually $55 \%-75 \%$ ) of the income of the sector. Therefore the CSO sector is highly institutionalized and also highly dependent on the government for ongoing support. Since the government also needs the CSO sector, there is a kind of interdependence, termed «hierarchical interdependence», between the two sectors. In France the government also started to revise its policies of subsidizing the CSO sector for its function of «solidarity», introducing grants and contracts based on performance in delivering projects and services since 2008-2010.

Emerging (Mediterranean and CEE): in the Mediterranean countries (e.g. Greece, Cyprus, Portugal) and most Central and Eastern European countries the relationship between the state and CSOs is still evolving. It has been characterized by low levels of public funding; either neglect of CSOs or dependency relationships; traditions or nepotism or political interest in funding and involvement of CSOs in service provision. Welfare models are typically residual as well as rudimentary as much of the care remains with the family and social nets. However, according to Sator (2010: 17) as the countries' economy and CSO sector develop, they will be likely to converge towards one of the other three models, he claims that Hungary and Czech Republic moves to corporatist model, Estonia and Slovakia tend toward to the liberal model, but Slovenia and Latvia towards Scandinavian model. 
In the Ukrainian case the lack of strategic vision from the state and consensus from the NGOs end experts' networks and coalitions led to the situation that optimal model is still not founded and civil society gets into dependence but mostly from foreign donors and untransparent business.

Ukrainian Statistic Service's annual reports show that more than half of all costs NGOs get from large donors, mostly foreign and international organizations, while less than 10
$\%$ - from national and local public budgets. Other costs of the third sector come from private donations, members' fees and social entrepreneurship. In total Ukrainian civil society institutions succeeded to collect 7,35 billions UAH, and as there was during previous years less than $10 \%$ came from the public budgets. The structure of Ukrainian nongovernmental organizations incomes during 2010-2018 presented in the Table 2.

Structure of Incomes of Ukrainian Non-Governmental Organizations in 2010-2018 (thousands, UAH)

\begin{tabular}{|c|c|c|c|c|c|c|c|c|c|c|c|}
\hline \multirow[b]{2}{*}{$\begin{array}{l}\text { Ukr } \\
\text { aine } \\
\text { / } \\
\text { Yea } \\
\text { r }\end{array}$} & \multirow[b]{2}{*}{$\begin{array}{l}\text { Costs } \\
\text { receive } \\
\mathrm{d}, \text { in } \\
\text { total }\end{array}$} & \multirow[b]{2}{*}{$\begin{array}{c}\text { From } \\
\text { the } \\
\text { State } \\
\text { Budget }\end{array}$} & \multirow[b]{2}{*}{$\begin{array}{c}\text { From } \\
\text { the } \\
\text { local } \\
\text { budg } \\
\text { ets }\end{array}$} & \multirow[b]{2}{*}{$\begin{array}{l}\text { Mem } \\
\text { bers' } \\
\text { Fees }\end{array}$} & \multirow[b]{2}{*}{$\begin{array}{l}\text { Charity } \\
\text { activiti } \\
\text { es, in } \\
\text { total }\end{array}$} & \multicolumn{3}{|c|}{$\begin{array}{l}\text { Among them /Source of } \\
\text { Charity }\end{array}$} & \multirow[b]{2}{*}{$\begin{array}{l}\text { From } \\
\text { the } \\
\text { econo } \\
\text { mical } \\
\text { activi } \\
\text { ties } \\
\text { by } \\
\text { CSOs }\end{array}$} & \multirow[b]{2}{*}{$\begin{array}{l}\text { Other } \\
\text { Sourc } \\
\text { es }\end{array}$} & $\begin{array}{c}\text { Includi } \\
\text { ng }\end{array}$ \\
\hline & & & & & & $\begin{array}{l}\text { From } \\
\text { the } \\
\text { Ukraini } \\
\text { an } \\
\text { firms } \\
\text { and } \\
\text { organiz } \\
\text { ations }\end{array}$ & $\begin{array}{c}\text { From } \\
\text { the } \\
\text { Ukraini } \\
\text { an } \\
\text { Citizen } \\
\text { s }\end{array}$ & $\begin{array}{l}\text { From } \\
\text { non- } \\
\text { resi- } \\
\text { dents }\end{array}$ & & & $\begin{array}{c}\text { Bank } \\
\text { and } \\
\text { financia } \\
1 \\
\text { entities } \\
\text { credits, } \\
\text { loans } \\
\text { etc }\end{array}$ \\
\hline 2018 & $\begin{array}{r}354 \\
061,7 \\
\end{array}$ & $\begin{array}{c}273 \\
327,2 \\
\end{array}$ & $\begin{array}{c}293 \\
094,1 \\
\end{array}$ & $\begin{array}{c}795 \\
579,7 \\
\end{array}$ & & 639,8 & $\begin{array}{c}430 \\
744,1\end{array}$ & & $\begin{array}{c}763 \\
769,8\end{array}$ & & 81,8 \\
\hline 2017 & $\begin{array}{l}7271 \\
566,8 \\
\end{array}$ & $\begin{array}{c}194 \\
032,2 \\
\end{array}$ & $\begin{array}{c}249 \\
852,9 \\
\end{array}$ & $\begin{array}{c}720 \\
475,7 \\
\end{array}$ & $\begin{array}{l}3805 \\
913,6 \\
\end{array}$ & $\begin{array}{l}1079 \\
589,9\end{array}$ & $\begin{array}{c}340 \\
694,9\end{array}$ & $\begin{array}{l}2385 \\
628,8 \\
\end{array}$ & $\begin{array}{l}1106 \\
304,1\end{array}$ & $\begin{array}{l}1194 \\
988,3\end{array}$ & 294,6 \\
\hline 2016 & $\begin{array}{l}6211 \\
967,7\end{array}$ & $\begin{array}{c}259 \\
549,5\end{array}$ & $\begin{array}{c}194 \\
230,5\end{array}$ & $\begin{array}{c}622 \\
970,5\end{array}$ & $\begin{array}{c}3523 \\
400\end{array}$ & $\begin{array}{c}879 \\
676,0\end{array}$ & $\begin{array}{c}351 \\
587,8\end{array}$ & $\begin{array}{l}2292 \\
136,2\end{array}$ & $\begin{array}{c}468 \\
782,8\end{array}$ & $\begin{array}{l}1143 \\
034,4\end{array}$ & 506,3 \\
\hline 2015 & $\begin{array}{l}6316 \\
489,1 \\
\end{array}$ & $\begin{array}{c}226 \\
339,4 \\
\end{array}$ & $\begin{array}{c}160 \\
461,7\end{array}$ & $\begin{array}{c}611 \\
605,4 \\
\end{array}$ & $\begin{array}{l}3712 \\
052,3\end{array}$ & $\begin{array}{l}1459 \\
721,4\end{array}$ & $\begin{array}{c}187 \\
347,6\end{array}$ & $\begin{array}{l}2064 \\
983,3\end{array}$ & $\begin{array}{c}549 \\
749,1\end{array}$ & $\begin{array}{l}1056 \\
281,2\end{array}$ & 496,3 \\
\hline 2014 & $\begin{array}{l}4101 \\
284,0\end{array}$ & $\begin{array}{c}180 \\
879,0\end{array}$ & $\begin{array}{c}97 \\
482,0\end{array}$ & $\begin{array}{c}454 \\
639,9\end{array}$ & $\begin{array}{l}1875 \\
253,8\end{array}$ & $\begin{array}{c}774 \\
760,0\end{array}$ & $\begin{array}{c}199 \\
888,2\end{array}$ & $\begin{array}{c}900 \\
605,6\end{array}$ & $\begin{array}{c}510 \\
897,3\end{array}$ & $\begin{array}{c}982 \\
132,0\end{array}$ & 546,2 \\
\hline 2013 & $\begin{array}{l}3754 \\
219,7 \\
\end{array}$ & $\begin{array}{c}266 \\
322,0 \\
\end{array}$ & $\begin{array}{c}135 \\
625,8 \\
\end{array}$ & $\begin{array}{c}499 \\
956,6 \\
\end{array}$ & $\begin{array}{l}705 \\
099,1 \\
\end{array}$ & $\begin{array}{c}827 \\
035,6 \\
\end{array}$ & $\begin{array}{c}172 \\
852,3 \\
\end{array}$ & $\begin{array}{c}705 \\
211,2 \\
\end{array}$ & $\begin{array}{c}528 \\
884,0 \\
\end{array}$ & $\begin{array}{c}618 \\
332,2 \\
\end{array}$ & 1485,4 \\
\hline 2012 & $\begin{array}{c}3694 \\
594,79\end{array}$ & $\begin{array}{c}290 \\
863,97\end{array}$ & - & $\begin{array}{c}533 \\
640,0\end{array}$ & $\begin{array}{c}1646 \\
590,98\end{array}$ & $\begin{array}{c}629 \\
037,29\end{array}$ & $\begin{array}{c}144 \\
008,12\end{array}$ & $\begin{array}{c}873 \\
545,57\end{array}$ & $\begin{array}{c}604 \\
059,8 \\
1 \\
\end{array}$ & $\begin{array}{c}619 \\
440,0 \\
3 \\
\end{array}$ & 324,39 \\
\hline 2011 & $\begin{array}{l}3370 \\
227,6\end{array}$ & $\begin{array}{c}271 \\
276,3\end{array}$ & - & $\begin{array}{c}475 \\
313,9\end{array}$ & $\begin{array}{l}1454 \\
156,4\end{array}$ & $\begin{array}{c}563 \\
936,4\end{array}$ & $\begin{array}{c}199 \\
955,2\end{array}$ & $\begin{array}{c}690 \\
264,8\end{array}$ & $\begin{array}{c}524 \\
975,2\end{array}$ & $\begin{array}{c}644 \\
505,8\end{array}$ & $\begin{array}{c}12 \\
459,2\end{array}$ \\
\hline 2010 & $\begin{array}{l}2763 \\
992,7\end{array}$ & $\begin{array}{c}220 \\
649,7\end{array}$ & - & $\begin{array}{c}388 \\
680,1\end{array}$ & $\begin{array}{l}1133 \\
814,6\end{array}$ & $\begin{array}{c}418 \\
196,0\end{array}$ & $\begin{array}{c}122 \\
077,4\end{array}$ & $\begin{array}{c}593 \\
541,2\end{array}$ & $\begin{array}{c}516 \\
557,8\end{array}$ & $\begin{array}{c}504 \\
290,5\end{array}$ & 711,6 \\
\hline
\end{tabular}

Composed by author based on Ukrainian Statistic Service Annual Bulletins, 2010-2019

From this data one can see that foreign donors are the most significant source for operational activities of Ukrainian civil sector, giving from one third to half of overall civic sector incomes, meanwhile the public funds (both of the state and local levels) seems to input less than 10 per cents of CSOs support. According to the Open Aid Ukraine portal supported by the Ministry of Economic Development and Trade, the biggest donors to Ukrainian CSOs include the European Union
(EU), USAID, and Sida. The Ministry of Economic Development reported that 264 new technical assistance projects from contributors such as USAID and the US government were registered in 2018 with $\$ 953$ million of total funding, a 50 percent increase from 2017. Traditionally, international technical assistance focuses on governance, citizen engagement, and regional development (CSOSI 2019: 233).

But according to the Ukraine Civil Society Sectoral Assessment Report (NORC 2018) 
provided by University of Chicago, foreign donor funding is weakly diversified with project grants and mostly available for professional CSOs with previous grant history. Newlyestablished and small CSOs as well as informal civic initiatives lack funding. Donor funding also falls short of encouraging CSOs to look for local sources of support (NORC 2018: 2-3, 4142).

As the foreign donors remains the most significant source for the civil society in general, and for obvious reasons (political and reforms focuses, global and European agenda, human rights and UN' sustainable development goals priorities) prefers to collaborate with the narrow list of organizations, in the short-term perspective this empowers these NGOs, which are really can be voice of the most progressive part of society, to be independent from political elites, advocating democratic changes, or to become the pool of human recourses for new political parties and governmental institutions. As Lutsevych pointed out that «international donors have helped to sustain an active cohort of citizens who have defended human rights, monitored elections, developed local communities, promoted free media, campaigned against domestic violence and mobilized for environmental causes» (Lutsevych, 2017: 60).

Indeed, after the Revolution of Dignity on 2014 and even after the crucial changes of political elites on 2019 in Ukraine there were a lot of examples when civil society leaders were incorporated in newly elected bodies or pushed some sectoral reforms efficiently. Western funding has played a critical role in CSO-led reform efforts. It is estimated that the volume of grants to Ukraine almost doubled after the Euromaidan. Around \$1 billion a year is now directed to reform-related projects, with roughly 30 per cent of this assistance channelled via civil society - making for an annual operation worth roughly $\$ 300$ million. USAID has doubled its assistance: in 2016 it allocated \$67 million to programmes supporting anticorruption efforts, good governance and civil society in Ukraine (Lutsevych 2017: 61).

European Union, being the biggest international donor for Ukrainian NGOs and the main partner of the government, couldn't pretend to propose any particular model of civic-state relations, but in the Ukraine - EU Country Roadmap for Engagement with Civil
Society 2014-2017 there were proclaimed two main objectives: 1) to strengthen the capacity and participation of CSOs in policy dialogue, monitoring and oversight, advancing the implementation of the national reform agenda; and 2) to contribute to foster a conducive environment for civil society, embodied in eight priorities, covered an enabling environment, policy analysis, legitimacy, the Association Agreement, conflict, accountability, human rights, economic development (EU Delegation to Ukraine 2015: 13-16).

In the Roadmap for 2018-2020 there was admitted that areas in which CSOs work are largely donor-driven and financial sustainability in between projects remains a problem and on local and regional level organisations tend to be competitive, rather than cooperative (EU Delegation to Ukraine 2019: 2), what was one of the main obstacle to create an efficient network and coalitions coupled with a lack of capacities and skills among the civil activists and NGOs employees to apply for a grants.

These trends in foreign donors support recreates structural inequality between the experienced organizations which are capable to cooperate or monitor the government and based in the capital city and those which appeared in regions and working with target groups in local communities. Being sufficient contribution in today's Ukrainian civil sector development, in the middle-term perspective this strategy of donors could affect the cleavages within Ukrainian third sector and strengthen its negative public image as «grant eaters» and «foreign agents». As to the long-term perspective the main issue will be the availability of such a funds for Ukrainian civil society and diversification of the incomes.

At the moment public image of NGOs is pretty positive, as to the all-Ukrainian sociological poll «Civil Society in Ukraine: the views of citizens» published by the Democratic Initiatives Foundation on October 2019 (DIF, 2019) half of the Ukrainian citizens admitted that NGOs are really useful for their cities and communities $(58 \%$ in the Western Ukraine, 52 $\%$ in the Center, $54 \%$ in the Eastern Ukraine and only $36 \%$ on South), meanwhile $20 \%$ are consider them not to be necessitate. But only about $7 \%$ of citizens identify themselves as NGO members and less than $20 \%$ took part in any civic initiative during previous year. 
Вісник ХНУ імені В. Н. Каразіна, серія «Питання політології», вип. 36, 2019

Table 3.

Indicators of Civic Activism and Public Trust to NGOs in Ukraine (2012-2019)

\begin{tabular}{|l|c|c|c|c|c|c|}
\hline $\begin{array}{l}\text { Engagement of Citizens } \\
(\%)\end{array}$ & $\begin{array}{c}\text { December } \\
2012\end{array}$ & $\begin{array}{c}\text { November } \\
2015\end{array}$ & $\begin{array}{c}\text { December } \\
2016\end{array}$ & $\begin{array}{c}\text { December } \\
2017\end{array}$ & $\begin{array}{c}\text { December } \\
2018\end{array}$ & $\begin{array}{c}\text { August } \\
2019\end{array}$ \\
\hline $\begin{array}{l}\text { Engagement in any civic } \\
\text { activities (\%) }\end{array}$ & 8,1 & - & - & 6,6 & 9,8 & 7,5 \\
\hline $\begin{array}{l}\text { Membership in NGOs } \\
(\%)\end{array}$ & 4,2 & & & 2,9 & 3,8 & 2,6 \\
\hline $\begin{array}{l}\text { Volunteering activities } \\
(\%)\end{array}$ & 10,2 & 13,0 & 14,0 & 12,3 & 18,3 & 9,3 \\
\hline $\begin{array}{l}\text { Charity / Donations } \\
\text { (including clothes and } \\
\text { staff, \%) }\end{array}$ & 28,9 & 47,0 & 41,6 & 41,4 & 38,5 & 25,1 \\
\hline Public trust to NGO (\%) & 37 & 44 & 45,0 & 37,0 & 43,4 & 45,2 \\
\hline
\end{tabular}

Composed by author based on ENGAGE Public opinion survey to assess the changes in citizen's awareness of civil society and their activities (I-III waves 2015-2018); Democratic Initiatives Poll «Civil Society in Ukraine: the views of citizens» (2019).

According to the National Civic Engagement Poll (USAID/ ENGAGE, 2019) conducted by the research agency Info Sapiens, during JuneJuly 2019, four out of ten Ukrainians (44.4\%) hypothetically are ready to contribute to a civil society organization they trust. Household income levels are correlated with readiness to support social causes, but not as much as one might expect. Even among those who do not have enough subsistence income, $39.4 \%$ are ready to contribute some funds to initiatives. The level of education is the strongest factor influencing the willingness to fund civic initiatives: the higher the education, the greater the likelihood to support civic initiatives. Interesting that mostly people in Ukraine are ready to donate small sums up to 100 UAHs (26 $\%)$ or from 100 to 1000 UAH (13\%), 4,6 \% would ready to contribute a certain amount or percentage of the income to civil society initiatives regularly.

But one of the main problem that at the moment Ukrainian citizens has very controversial image of the added value that civil society creates in their country and what role in should play. From the one point of view the vast majority of the people $(77 \%)$ that the state should stimulate the civil society' development and only $9 \%$ per cents stay on contrary opinion (Democratic Initiatives 2019). But, as to the data of National Civic Engagement Poll (2019), $19 \%$ of respondents are certain that state should finance CSOs and only $8 \%$ think that Ukrainian citizens have to contribute to civil society financially.



FigFigure 3. Distribution of responses to the question «Who do you think should finance civil initiatives/NGOs?», USAID/ ENGAGE National Civic Engagement Poll survey's data (2019). 
Among the reasons that motivate citizens to contribute to a civil society organization, respondents continue to be influenced by clear objectives or goals and the results of a civic initiative $(38.4 \%)$. The second most influential factor is citizens' trust in a civil society organization, important for $31.9 \%$ of respondents. Transparent management of funding is considered to be a significant factor as well, according to $29.7 \%$ of Ukrainians.

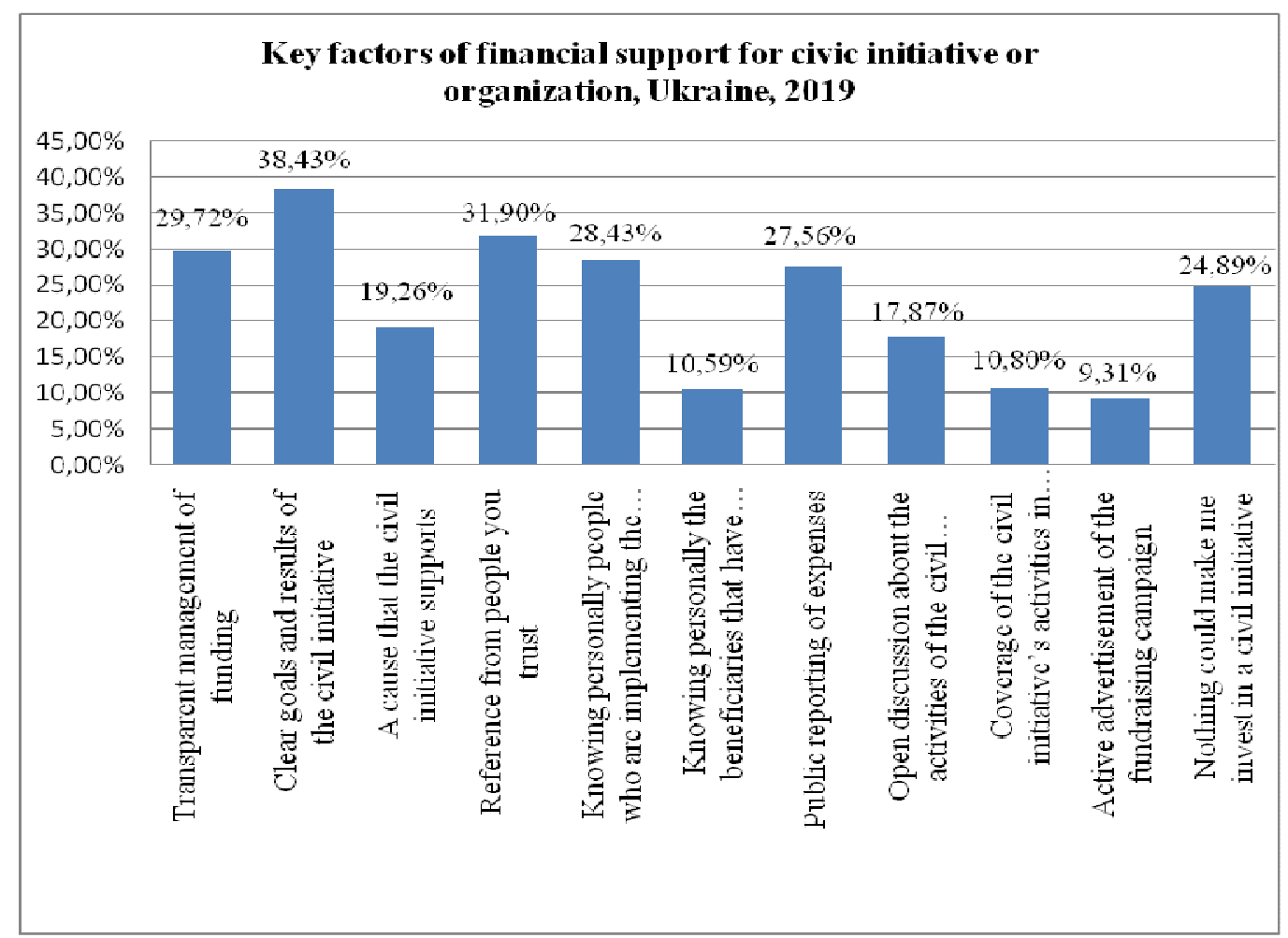

Figure 4. Key factors that motivate Ukrainian citizens to contribute to a civil society organization or initiatives (up to 3 options to choose), 2019. Composed by author based on USAID/ ENGAGE National Civic Engagement Poll syrvey's data (2019).

These reasons, named by Ukrainian citizens, are close to that, pointed out in the research by Bullain and Hadzi-Miceva (2009) conducted for the European Center for Not-for-Profit Law. They emphasize the most important factors of public and private donations are to be the accountability and transparency of civil sector. Accountability is generally understood there as an obligation or willingness by the NPO to accept responsibility or to account for its actions. Accountability means that the NGO holds itself accountable towards its multiple stakeholders and ensures that it meets the various stakeholder needs and interests (including beneficiaries, donors, government, policy makers, volunteers etc., as well as the public at large). This includes the following key elements:

- compliance with legal obligations;

- demonstrating how resources are spent and how these respond to the mission and obligations taken towards stakeholders;
- good governance;

- prudent financial management;

- demonstrating goodwill or an intent to meet certain professional and management standards;

- demonstrating regularly that it uses its resources wisely and does not take advantage of its special privileges (e.g., tax exemptions) to pursue activities contrary to its nonprofit status (Bullain \& Hadzi-Miceva 2009: 11).

From that point of view civil organizations are far to demonstrate high level of accountability which based on some structural challenges such as small number of members and employees, lack of financial literacy among activists, predomination of short-term grants from the donors aimed mostly on concrete project implementation, than on institutional developments.

In the same research «transparency» is defined as an obligation or willingness of NPOs to publish and make available basic data about 
their operations, including organizational, financial and programmatic data as well. An NGO is transparent if it readily opens and makes available its accounts and records to public scrutiny by funders, beneficiaries, and others. There are some structural components of the civil society organizations transparency among which:

- Organizational transparency means availability of the basic data regarding the establishment and registration of the NGO that allows third parties to identify the NPO and seek out its responsible officers for further information (e.g. name, seat address, decisionmaking body).

- Programmatic transparency includes basic data on activities and services which allows the government and the public at large to assess the effectiveness or efficiency of the NGO.

- Financial transparency is related to publishing financial reports about incomes, expenses and general financial health that are required by the legal frameworks of the given country. Further, the entirety of data and information presented by the NGO should provide third parties with an overall understanding as to the nature of operations of the organization (Bullain \& Hadzi-Miceva 2009: 12).

Since the new Law on Civic Organizations in Ukraine was adopted in 2012, the Unified Register of Civil Organizations became available on-line, what increased the organizational transparency of the third sector in Ukraine in general. Those NGOs which has the status of legal entity are oblige to report annually on their financial incomes and spending to the Fiscal service as well to the Statistic Service, but only about half from 82 thousands of NGOs registered in Ukraine as on the January $1^{\text {st }}, 2019$, do that regularly. If those organizations which collaborated with foreign donors and public authorities provide their financial reports to these bodies, mostly NGOs are not transparent to their stakeholders, target groups or citizens taken in large.

Taking to account public opinion regarding the sources of civic organizations finances and economic inequality in Ukrainian society the most significant purposes for the next national strategy should be the concentration on reduction of the dependence from foreign donors, increasing the share of public funds (both national and local), stimulation of both charity from the business side and the social entrepreneurship.

Earned income can help a CSO finance its administrative or developmental needs and as such plays a very important role in CSO sustainability. In fact, in most countries earned income represents the major part of the income of the CSO sector (Sator 2010). CSOs' economic activities and social entrepreneurship can be an innovative and useful way for some Ukrainian NGOs to maintain financial independency as well as the option of integrating some social categories into a normal social life in local communities. If to go back to the statistic data provided above, the own income from economic activities tended to grow more than double from UAH 467 million (approximately $\$ 17,3$ million) in 2016 to $\mathrm{UAH}$ 1,106 billion ( $\$ 40,9$ million) in 2017 , reduced then to UAH 764 million in 2018 (State Statistic Service of Ukraine 2019).

One of the reason of such sporadic development lies in inadequacy of legal framework: Ukraine does not have a special law on social entrepreneurship, meanwhile the Law on Civic Organizations is open to interpretation by the tax authorities, therefore, CSOs are faced with difficulties when utilising their rights to engage in economic activities, due to rigid interpretation of accompanying rules and obligations by tax authorities. There is a need to distinguish a social entrepreneur from others. Moreover, there is a lack of consistency from donors and others on what constitutes a social enterprise and its applicability. Companies who are socially responsible and CSOs who have economic activities, should not be confused with social enterprises. It is possible that some aspects of a social enterprise can be accommodated through changes to associated laws (labour law, fiscal law, social benefits law), rather than having a law on social enterprise as such (EU Delegation to Ukraine 2019).

As to the state support for CSOs in Ukraine there were some funds managed by particular Ministries, such as the Ministry of Social Policy, Ministry of Youth and Sport, and Ministry of Culture allocated a combined total of \$13.6 million for CSO funding, an increase of 1.7 times compared to 2017 and 2016. But contrary to the National Strategy for Supporting the Civil Society Development in Ukraine (2019) and to expectations of experts and civil activists, these state bodies mostly used the old approach of direct funding for concrete organizations, and less percentage of state budget was provided on a competitive basis after the long avocation and pressure from civil society and attention from international organizations' side. 
For example, the Ministry of Social Policy alone allocated \$3.7 million to CSOs serving veterans and people with disabilities in 2018. That year, after pressure from veterans' associations, it for the first time ran a competitive tender process for non-profit organizations of veterans and has awarded UAH 19 million $(\$ 692,000)$ to 80 such organizations (Boulègue, Lutsevych and Marin 2018: 19). The Ministry of Youth and Sport selected forty-one CSOs to implement fifty-seven projects focused on youth and children with a total budget of UAH 11 million (approximately $\$ 408,000$ ) meanwhile they provided grants to nineteen CSOs to implement thirty national and patriotic projects with a budget of UAH 7 million (approximately \$270,000), almost twice as much as was awarded in 2017 (UAH 4 million). The most positive practices of contests and competitions were implemented by the Ukrainian Cultural Fund, a public institution, conducted three funding contests that provided full and partial support for 298 CSO projects with budgets of UAH $148,770(\$ 5,500)$ each (USAID CSOSI, 2019: 233). The experience of Ukrainian Cultural Fund shows that, independent boards, transparent rules, competitive approach and positive image of newly established institution are more attractive for civil society to cooperate with the governmental authorities.

Due to the decentralisation reform what was recognized as most significant and successful in post-Euromaidan Ukraine large costs are cumulated on the level of local communities. This provides a lot of opportunities to CSOs, therefore they could compete for grants, municipal and regional public funds, as well as to provide social services in the partnership with local self-government bodies. The social entrepreneurship is also the phenomenon closely related to particular community needs meanwhile accumulating costs from individuals and business traditionally works better on the level of personal contacts. Regardless the fact that participatory budgets become more and more widespread in Ukraine, the model of interrelations between the local authorities and civil society still depends of political will. That's why to establish strategic goals and clear rules on legislative level is demanded The changes in legislation on obligatory public consultations, on local self-government (in the part on local initiatives, public hearing, regional grants and funds), on social entrepreneurship and social services are considered to be the first step to establishing the institutional culture of cooperation of local authorities and civil society.

Conclusions. The issue of financial sustainability remains one of the most challenging for Ukrainian civil society: from the one side most known and capable of them depends from international donors, from the other side shifts toward to the closer cooperation with the state or local authorities' make NGOs more depended from political actors and influence badly on their public image.

There could be at least three paths to achieve financial sustainability for Ukrainian third sector connected with three strategic dilemmas: first is to play role of independent monitors and neutral policy influencers getting funds from international donors, second is to increase public funding for NGOs on state, regional and local level though national grants' system, open calls and contests, implementing participatory budgets etc., choosing between corporativism and Scandinavian model. And the third option for NGOs is to move to the market-oriented liberal model and to sell their services to domestic actors, including business, interest groups, local authorities and political parties. Taking to account public opinion regarding the sources of civic organizations finances and economic inequality in Ukrainian society the most significant purposes for the next national strategy should be the concentration on reduction of the dependence from foreign donors, increasing the share of public funds (both national and local), stimulation of both charity from the business side and the social entrepreneurship.

Every of these paths includes its own risks and perspectives, and definitely the choice depends not only on civil society organizations' preferences but on social expectations, political environment and state's strategy which drives to the necessity of renewing broad dialogue between civil society, political elites, government and international donors in the new political circumstances.

\section{REFERENCES}

Cooper, R. 2018. What is Civil Society? How is the term used and what is seen to be its role and value (internationally) in 2018? K4D Helpdesk Report. Brighton, UK: University of Birmingham, Institute of Development Studies.

VanDyck, C., K. 2017. Concept and definition of civil society sustainability. Washington DC: Centre for Strategic and International Studies. URL: https://csisprod.s3.amazonaws.com/s3fspublic/publicati 
on/170630_VanDyck_CivilSocietySustainability_Web. pdf?QfxMIeHr9U8aeV1kOjF o.FBTsLG76HP

World Economic Forum (2013). The Future Role of Civil Society. World Economic Forum in collaboration with KPMG International. URL http://www3.weforum.org/docs/WEF_FutureRoleCivil Society Report 2013.pdf

Anheier, H. K. (2004), Civil Society: Measurement, Evaluation, Policy, London: Routledge. Jezard, A. 2018. Who and what is 'civil society?' World Economic Forum Agenda article, 23 April 2018 URL: https://www.weforum.org/agenda/2018/04/whatis-civil-society/

Hale, H. E. 2014. Patronal Politics: Eurasian Regime Dynamics in Comparative Perspective, Cambridge University Press, Cambridge.

Lutsevych O. 2017. "Civil Society" in The Struggle for Ukraine. Chatham House Report. Ash T., Gunn J., Lough J., Lutsevych O., Nixey J., Sherr J. and Wolczuk K. London: The Royal Institute of International Affairs Chatham House: 59-71.

Way L.. 2014. "The Maidan and Beyond: Civil Society and Democratization”. Journal of Democracy. Johns Hopkins University Press. Vol. 25. № 3: 35-43.

Burlyuk O., Shapovalova N. (eds.). 2018. Civil Society in Post-Euromaidan Ukraine. From Revolution to Consolidation. Columbia University Press.

Smagliy, K.. 2017. A Wake-up Call for Ukraine's Civil Society. Kennan Cable. 25. August 2017. Washington DC: Woodrow Wilson International Center for Scholars. https://www.wilsoncenter.org/sites/default/files/kennan _cable_25_-_smagliy.pdf

USAID. 2019. The 2018 CSO Sustainability Index for Central and Eastern Europe and Eurasia. 22nd Edition. Washington DC: United States Agency for International Development, Bureau for Democracy, Conflict and Humanitarian Assistance Center of Excellence on Democracy, Human Rights and Governance.

URL: https://www.fhi360.org/sites/default/files/media/docum ents/resource-csosi-2018-report-europe-eurasia.pdf

USAID. 2018. CSOSI for Europe and Eurasia 2013-2018. Washington DC: United States Agency for International Development.

https://csosi.org/?region=EUROPE

USAID. 2013. Europe and Eurasia CSOSI Data 1997-2012. Washington DC: United States Agency for International Development. URL: https://www.usaid.gov/documents/1863/europe-andeurasia-csosi-data-1997-2012

National Strategy for Supporting Civil Society Development for 2016-2020. 2016. Decree by the President of Ukraine № 68/2016. URL: https://www.president.gov.ua/documents/68201619805

Sator, Balazs. 2010. International Practicies on Funding Civel Society Organizations. Kyiv: OSCE Project Coordinator to Ukraine.
State Statistic Service of Ukraine. 2017. Activities of Non-Governmental Organizations in Ukraine. Annual Bulletin (2010-2016). URL: http://www.ukrstat.gov.ua/druk/publicat/Arhiv_u/15/Ar ch_go_bl.htm

State Statistic Service of Ukraine. 2019. Activities of Non-Governmental Organizations in Ukraine Activities of Non-Governmental Organizations in Ukraine in $2018 . \quad$ URL: http://www.ukrstat.gov.ua/operativ/operativ2019/susp_ d/susp_d_2018.xls

NORC. 2018. Ukraine Civil Society Sectoral Assessment. Tasking 074. NORC, University of Chicago. August $2018 . \quad$ URL: https://pdf.usaid.gov/pdf_docs/PA00TDQ5.pdf

EU Delegation to Ukraine. 2014. Ukraine-EU Country Roadmap for engagement with Civil Society 2014-2017. Ref. Ares (2014)2557900-01/08/2014. Brussels: EU-EEAS. URL: https://europa.eu/capacity4dev/public-governancecivilsociety/document/ukraine-roadmap-engagementcivil-society

EU Delegation to Ukraine. 2019. Ukraine-EU Country Roadmap for engagement with Civil Society 2018-2020. Brussels: Press and information team of the Delegation to Ukraine URL:. https://eeas.europa.eu/sites/eeas/files/roadmap_for_cs. pdf

ENGAGE Project. 2018. Public opinion survey to assess the changes in citizen's awareness of civil society and their activities (I-III waves 2015-2018). Kyiv: Pact Inc. URL: https://dif.org.ua/uploads/pdf/3235987555af01ce02675 50.88880763.pdf

Democratic Initiatives Foundation. 2019. Civil Society in Ukraine: the views of citizens. Results of Public Opinion Survey. URL: https://dif.org.ua/en/article/the-dissatisfaction-ofukrainians-with-the-current-government-is-growingwhile-trust-of-civil-activists-increases

USAID/ENGAGE. 2019. National Civic Engagement Poll. Kyiv: Pact Inc. Info Sapiens. 8 October 2019 URL: https://dif.org.ua/en/article/civilactivism-and-attitudes-to-reform-public-opinion-inukraine_5

Bullain, Nilda \& Hadzi-Miceva Katerina (2009) Study on Recent Public and Self-Regulatory Initiatives Improving Transparency and Accountability of NonProfit Organisations in the European Union. Budapest: European Center for Not-for-Profit Law URL: http://ecnl.org/dindocuments/306_ECNL\%20Accounta bility\%20Study_published\%20on\%20DG\%20JLS.pdf

Boulègue M., Lutsevych O., Marin A.. (2018) Civil Society Under Russia's Threat: Building Resilience in Ukraine, Belarus and Moldova. London: Chatham House, the Royal Institute of International Affairs. 